\title{
The Influence of Internet Usage to Cyberbullying of SHS Students
}

\author{
Rey Avila Mangarin ${ }^{1}$, Marlon D. Montaño ${ }^{2}$ \\ ${ }^{I}$ The University of Mindanao (Panabo College) \\ ${ }^{2}$ The University of Mindanao (Peñaplata College)
}

\begin{abstract}
This study was conducted to determine the significant influence of internet usagetocyberbullying among Senior High School students of two campuses of a certain university in Davao Region, Philippines. A quantitative non-experimental descriptivecorrelational design was employed in the study utilizing a stratified random sampling technique among 176 out of 317 SHS students from Campus $A$ and 132 out of 197 students from Campus B for S.Y. 2019-2020. Percentage was used to determine the proportion of students under frequency of internet usage and cyber bullying while chi-square analysis was used in determining if internet usage is a significant predictive factor of cyber bullying. As a result, $50 \%$ of sample students used internet in daily basis. The proportion of sample students who used in weekly basis is $18.2 \%$. The proportion of students around $22.7 \%$ to be using internet in monthly basis. There is only a portion of $9.1 \%$ of sample students who used internet whenever they are only required.64\% of the sample students experienced cyberbullying while only $36 \%$ of the sample students responded that they haven't experienced cyberbullying. Thus, SHS students' exposure to internet is recommended to be in controllable manner to reduce the cyber bullying experiences of the students.
\end{abstract}

Keywords: internet usage, cyberbullying, SHS students

\section{INTRODUCTION}

\section{Background of the Study}

$\mathrm{T}$ The pressingsocial issues relative to internet usage and its consequences needs to be managed and penalization for behavior that may be characterized as cyber violence needs to be crafted and in place. The Government of Canada's national strategy on community safety and crime prevention was created in 1998 to support and assist victims including children, adults and minorities. At the community level in Canada local school Boards in concert with provincial Ministries of Education have published resource booklets on Cyberbullying to try to reach all Canadians. Still there is more to do to be proactive. In Canada, the province of Ontario introduced new legislation concerning cyberbullying as it is now an offence for which a student can be suspended or expelled from school (CityNews, 2007).

In numerous studies, the partake in tormenting and fortifying each other's harassing practices was given clear emphasis (Anderson, 2012). While the nature of the internet is one of the elements that influences young people's cooperation in tormenting. This is on the grounds that the internet permits people to act with private characters ( $\mathrm{Li}, 2007)$. An investigation of Hitam and Idrus (2014) uncovered that ladies are bound to take part in online correspondence to keep up close to home associations and for learning inclinations, though men utilize online correspondence for seeking after sexual premium and sentiment.

These days, web-based life stages are utilized for different reasons whether be it for long range informal communication, social advertising, learning and instructive purposes, joy and once in a while utilize adversely, for example, digital harassing, stereotyping, sex entertainment and even a go-to put for discouraged individuals. Young people today are not by any means mindful now only a solitary post of their own subtleties can influence their security. In this study about internet usage and cyberbullying, many researchers study about thesevariables. This research has global, national, and local research some of internet use have a positive and negative the positive effect of internet usage to get some knowledge for negative effect is cyberbullying.

\section{THEORETICAL FRAMEWORK}

This study is anchored on the proposition of Williams (2014) that as communication becomes more technology based with less emphasis on in-vivo communication, it is important to understand the effects of prolonged technology use (specifically Internet usage) on interpersonal interactions. Moreover, internet usage has been found to impact how people express and understand social cues. Also, cyberbully status was found to be a moderator for the relationship.

Also, the proposition of Savoldi and Ferraz de Abreu (2016) that there was a relationship between bullying, cyberbullying and Internet usage using the conceptual framework of social capital theory.

Lastly, the proposition of Joinson (1998) that internet allows for unbridled communication, it also seems to encourage a measure of mean-spiritedness. When students think they can remain anonymous, they are less inhibited in saying things they never would say to a person face-to-face.

\section{CONCEPTUAL FRAMEWORK}

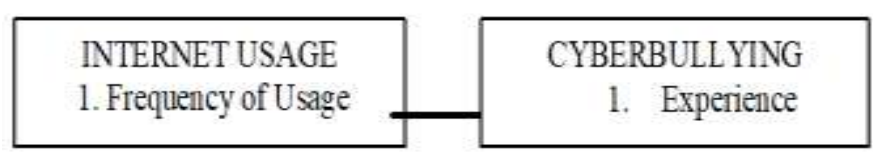

Figure 1: The Conceptual Paradigm Showing the Variables of the Study 
The independent variable is the internet usage which is defined as the exposure of the students in the internet. This is indicated by frequency of usage with three categories which are every day which refers to daily use of students of internet regardless of what they do, every week which refers to the use of internet once in a week, and when required which refers to students' exposure only when asked or required.The dependent variable is cyberbullying which refers to the experience of the students being bullied in the internet regardless of what form and this is indicated with a Yes and No response if experienced or not.

\section{Research Objectives}

The main purpose of this study was determine the significant association between internet usage and cyberbullying among SHS students in two campuses of certain university in Davao Region. Specifically, this aimed:

1. To determine the proportion of students who used internet:
1.1. every day,
1.2. once a week,
1.3. once a month, and
1.4. when only required.

2. To determine the proportion of students who:

2.1. Who experienced cyberbullying, and

2.2. Who didn't experienced cyberbullying.

3. To determine the significant association between internet usage and cyberbullying among SHS students in two branches of certain university in Davao Region.

\section{Hypothesis}

The hypothesis that there was no significant association between internet usage and cyberbullying among SHS students in two branches of certain university in Davao Region was tested at 0.05 level of significance.

\section{RESEARCH DESIGN}

This study utilized quantitative non-experimental descriptivecomparative survey research. The utilization of this design is justified by McCombs (2019) in order to accurately and systematically describe a population, situation or phenomenon, a descriptive research design can be used to investigate one or more variables. This design is appropriate in this study because like the function of this design, this study described the frequency of students who used internet in daily basis, weekly basis, monthly basis, and when required only and also the proportion of students who experienced bullying out from the sample parameter.

\section{Research Locale}

This study was in two cities of certain province in Davao del Norte where the two campuses of certain university was located. The first city was Panabo City. The City of Panabo is a third class city in the province of Davao del Norte, Philippines. It is a coastal component city in the province of Davao del Norte with a land area of 251.23 square kilometers which constitutes $7.33 \%$ of Davao del Norte's total area. Panabo has
40 barangays. The city center of Panabo is situated at approximately $7^{\circ} 18^{\prime}$ North, $125^{\circ} 41^{\prime}$ East, in the island of Mindanao. Elevation at these coordinates is estimated at 6.5 meters or 21.3 feet above mean sea level.

The second city was Island Garden City of Samal where Campus B was located. Samal, officially the Island Garden City of Samal is a 4th class component city in the province of Davao del Norte, Philippines. According to the 2015 census, it has a population of 104,123 people. It is made up of Samal Island and the smaller Talikud Island in the Davao Gulf, from the merger of former municipalities of Samal, Babak, and Kaputian.Samal is a part of the Metropolitan Davao area and is two kilometers away from Davao City, the largest city and the primary economic center of Mindanao.

\section{Research Respondents}

The respondents of the study were the SHS students of two campuses of a certain university in Davao Region. Campus A was located in the City of Panabo where 176 out of 317 SHS students from Campus A and 132 out of 197 students from Campus B which is located from Island Garden City of Samal, were randomly selected. The use of stratified random sampling techniques was considered in the selection of respondents. Additionally, the use of stratified random sampling technique is justified by Ang-ug, Casocot, Garcia, and Tado (2014) that in order for each strata yo be well-represented, the use of random selected based on the strata must be observed.

\section{Statistical Treatment}

Statistics needed to answer the sub-problems were as follows:

Frequency/Percentage: This was used to determine the proportion of students who used internet in daily, weekly, monthly, and whenever required only. Also, this was used to determine the proportion of students who experienced and did not experienced cyberbullying.

Chi Square Analysis: This was used in testing the significant association between internet usage and cyberbullying.

\section{Research Instrument}

A researcher-made questionnaire was the instrument used to determine the frequency of internet usage of the students and as well as to determine if the students experienced cyberbullying. The first part is just a checklist asking which of the four options applies to them when it comes to usage of internet. The second part only requires them to respond in a YES or NO answer whether they have experienced cyberbullying or did not. Since the data collected were in artificial nominal form, no level of two parameters were measured but only the proportion of students to which group they belong relative to internet usage and cyberbullying experience.

\section{RESULTS AND DISCUSSION}

\section{The Proportion of SHS Students Relative to Internet Usage}

The table below shows the distribution of students to four categories of frequency in using internet: 
Of all four categories, $50 \%$ of the sample students used internet in daily basis which put the category of daily usage to be the number 1 . This is followed by proportion of students around $22.7 \%$ to be using internet in monthly basis. Third in rank is thrpropotion of students who used in weekly basis comprising $18.2 \%$ while there is only a portion of $9.1 \%$ of sample students who used internet whenever they are only required.

Table 2: The Proportion of SHS Students Relative to Internet Usage

\begin{tabular}{|c|c|c|}
\hline Category & $\begin{array}{c}\text { Number of } \\
\text { Students }\end{array}$ & Percentage \\
\hline Daily & 154 & $50 \%$ \\
\hline Once a Week & 56 & $18.2 \%$ \\
\hline Once a Month & 70 & $22.7 \%$ \\
\hline When Only Required & 28 & $9.1 \%$ \\
\hline
\end{tabular}

This indicates that there is a prevalent use of internet among SHS students whatever purpose they may have. But it can also be noted that there are still who only use whenever they are required to which is an indication that it might be due to availability of resources to access the internet. Moreover, since the data only categorize based on frequency of usage, it can be further noted that limitations on the internet access can be based on the resources that students have.

The above result can be used in comparing with the study of Nahar, Hasan, Chowdhury, Khan, and Zayed, (2020) that the habituation rate of Internet where respondents are used $75.80 \%$ internet daily basis where library used rate is only $11.29 \%$. Also, Denisova, Kruchkova, AKlimova and Borokhovski (2019) added that tudents who spend online less than three hours a day will be more active, extroverted and confident in their real life (offline) than those who spend more time online. The importance of individual components in the hierarchy of educational values is associated with the features of self-awareness, self-attitude. Self-appraisal, selfconfidence, sense of independence and high appreciation of one's individuality are associated with a greater intellectual need, a more active and conscious desire to improve their own competence.

\section{The Proportion of SHS Students Relative to Cyberbullying}

The table below shows the distribution of students to two categories of frequency in using internet:

Of the two categoriescategories, $64 \%$ of the sample students experienced cyberbullying which is majority of the sample while only $36 \%$ of the sample students responded that they haven't experienced cyberbullying.

Table 2: The Proportion of SHS Students Relative to Cyberbullying

\begin{tabular}{|c|c|c|}
\hline Category & $\begin{array}{c}\text { Number of } \\
\text { Students }\end{array}$ & Percentage \\
\hline $\begin{array}{c}\text { Experienced } \\
\text { Cyberbullying }\end{array}$ & 197 & $64 \%$ \\
\hline $\begin{array}{c}\text { Did Not Experienced } \\
\text { Cyberbullying }\end{array}$ & 111 & $36 \%$ \\
\hline
\end{tabular}

This indicates that there is a prevalent cyberbullying happening in the internet world whatever forms it was. But it can also be noted that there are still who did not experienced cyberbullying even if they are exposed in the internet. However, since this study only limits on the response of students whether they experienced or not, it can be further renowned whether students have the full knowledge of having experienced cyberbullying.

In the study conducted by International Journal of Environmental Research and Public Health (2021), it was found out that $7.4 \%$ of respondents are tolerant of bullying and cyberbullying. This group of subjects was composed of $81.8 \%$ males and $18.2 \%$ females. Among them, $39.3 \%$ attend a technical college, $36 \%$ a vocational college and the remaining $24.8 \%$ a high school. More specifically, the percentage of students who are tolerant of bullying and cyberbullying rises to $9 \%$ among foreigners, while stands at $7.2 \%$ among Italians.

\section{The Significant Association between Internet Usage and Cyberbullying}

The table below shows the significant association between internet usage and cyberbullying:

Using Chi-Square Analysis, it has been found out that there is a significant association $\quad\left(X^{2}\right.$-value $=157.59 ; \quad p$ value $<0.05$ )between internet usage and cyberbullying. It can be noted that the frequency of using internet has been an influential factor in cyberbullying among SHS students. Moreover, the frequency of use of internet is a contributing factor whether or not the students experienced cyberbullying.

Table 3: The Significant Association between Internet Usage and Cyberbullying

\begin{tabular}{|c|c|c|}
\hline Variable & $\mathrm{X}^{2}$-value & p-value \\
\cline { 1 - 2 } Internet Usage & 157.59 & \multirow{2}{*}{0.000} \\
\hline Cyberbullying & & \\
\hline
\end{tabular}

In the study of Williams (2014), it was indicated that there was a significant relationship between Internet usage and in-vivo aggression; such that as Internet usage increased, in-vivo aggression increased. Cyberbully status was found to be a moderator for this relationship. Also, the proposition of $\mathrm{Li}$, Luo, Lin, and Shadiev (2018) students' internet usage and cyberbullying behaviors and the relationships between the two found to be significant. Moreover, the relationship between bullying, cyberbullying and internet usage in the post-has been justified to be supporting the above results by Savoldi and Ferraz de Abreu (2016).

\section{CONCLUSION}

1. $50 \%$ of sample students used internet in daily basis. The proportion of sample students who used in weekly basis is $18.2 \%$. The proportion of students around $22.7 \%$ to be using internet in monthly basis. There is only a portion of $9.1 \%$ of sample students who used internet whenever they are only required. 
2. $64 \%$ of the sample students experienced cyberbullying while only $36 \%$ of the sample students responded that they haven't experienced cyberbullying.

3. There is a significant association between internet usage and cyberbullying.

\section{RECOMMENDATION}

1. School administrator, teachers, and parents are recommended to regulate the use of internet among students based on needs not just only allow students to use freely the internet. Students are also advised to self-regulate in accessing internet.

2. School administrator, teachers, and parents are recommended to monitor the use of internet among students to be able to monitor cyberbullying among the students. Students are also advised to report to authorities cyberbullying that they encountered.

3. It is recommended that the use of internet must be regulated in order to regulate cyberbullying.

4. Further research is recommended exploring internet usage in other dimension other than frequency like reasons why using internet usage. Also, cyberbullying dimension is recommended to be explored in qualitative in-depth analysis for further understanding other than frequency count of incidents as this study has.

5. Exploration of internet usage and cyberbullying in qualitative approach is also recommended.

\section{REFERENCES}

[1] Anderson, K.L.M. (2012). Cyber-bullying: The new kid on the block (Master's thesis). California State University, Department of Teacher Education. Retrieved from: https://dergipark.org.tr/download/journal-file/8291\#page=137

[2] Ang-ug, E.F., Casocot, N.T., Garcia, R.F., \&Tado, P.P. (2014). College Statistics. Davao City: Blue Patriarch Publishing House.

[3] Bullying and cyberbullying among italian adolescents: The influence of psychosocial factors on violent behaviours.
(2021). International Journal of Environmental Research and Public Health, 18(4), 1558. doi:http://dx.doi.org/10.3390/ijerph18041558

[4] CityNews (2007, April 16). Cyberbullying law introduced in Ontario. Toronto: ON. Retrieved from:https://eric.ed.gov/?id=EJ945026

[5] Denisova, E., Kruchkova, A., Klimova, N., \&Borokhovski, E. (2019). Students internet usage: Psychological and pedagogical aspects. Les Ulis: EDP Sciences. doi:http://dx.doi.org/10.1051/shsconf/20197006002

[6] Hitam, N. A, Idrus, S. Z. S. (December 2014). Social Media Use or Abuse: A Review. Retrieved from https://www.researchgate.net/publication/2811097

60_Social_Media_Use_or_Abuse_A_Review. Retrieved from:https://www.researchgate.net/publication/330466568_EFFEC TS_OF_SOCIAL_MEDIA_USAGE_TO_THE_SCHOOL_PERFO RMANCE_OF_THE_GRADE12_SENIOR_HIGH_SCHOOL_STU DENTS/link/5c414acd92851c22a37d661f/download

[7] Li, Q. (2007). New bottle but old wine: A research of cyberbullying in schools. Computers in Human Behavior, 23(4), 17771791. Retrieved from: https://dergipark.org.tr/download/journalfile/8291\#page $=137$

[8] Li, J., Luo, C., Lin, Y., \&Shadiev, R. (2018). Exploring chinese Youth's internet usage and cyberbullying behaviors and their relationship. The Asia - Pacific Education Researcher, 27(5), 383394. doi:http://dx.doi.org/10.1007/s40299-018-0397-y

[9] McCombs, S. (2019). Descriptive research. Retrieved from https://www.scribbr.com/methodology/descriptive-research/.

[10] Nahar, S., Hasan, K. B. M. R., Chowdhury, T. S., Khan, S., \&Zayed, N. M. (2020). BUSINESS STUDENTS' ATTITUDE TOWARDS INTERNET USAGE: A STRATEGIC ANALYSIS ON THE STUDENTS OF UNIVERSITY OF RAJSHAHI, BANGLADESH. Academy of Strategic Management Journal, 19(1), 1-6. Retrieved from https://search.proquest.com/scholarly-journals/business-studentsattitude-towards-internet-usage/docview/2382044609/se2? accountid $=31259$

[11] Savoldi, F., \&Ferraz de Abreu, P. (2016). Bullying, cyberbullying and internet usage among young people in post-conflict belfast. Cogent Social Sciences, 2(1) doi:http://dx.doi.org/10.1080/23311886.2015.1132985

[12] Williams, D. A. (2014). Young adult internet usage and aggression: In-vivo aggression in the era of cyberbullies (Order No. 3581432). Available from ProQuest Central. (1574873106). Retrieved from https://search.proquest.com/dissertations-theses/young-adultinternet-usage-aggression-vivo-era/docview/1574873106/se2? accountid $=31259$ 